\title{
Beneficial effects of angiotensin converting enzyme inhibition on renal function in patients with diabetic nephropathy
}

\author{
STAFFAN BJÖRCK, GUDRUN NYBERG, HENRIK MULEC, GÖRAN GRANERUS, \\ HANS HERLITZ, MATTIAS AURELL
}

\begin{abstract}
The effects of angiotensin converting enzyme inhibition with captopril were investigated in patients with diabetic nephropathy and hypertension. After nine days' treatment with captopril glomerular filtration rate was unchanged in 13 patients, whereas renal plasma flow had increased from 265 to $302 \mathrm{ml} / \mathrm{min} / 1.73 \mathrm{~m}^{2}$ body surface area $(p<0.05)$ and the filtration fraction had decreased from $14 \cdot 3$ to $12 \cdot 8 \%(p<0.025)$. During two years' treatment with captopril in 14 patients the mean arterial blood pressure had fallen by $5 \mathrm{~mm} \mathrm{Hg}(p<0.005)$ and the deterioration in glomerular filtration rate had decreased from 10.3 to 2.4 $\mathrm{ml} / \mathrm{min} /$ year $(\mathbf{p}<0 \cdot 005)$. There was no correlation between the fall in blood pressure and the reduction in the deterioration of glomerular filtration rate.

These findings suggest that the effects of angiotensin converting enzyme inhibition on renal haemodynamics protect renal function. Inhibitors of angiotensin converting enzyme should be considered for lowering blood pressure in patients with diabetic nephropathy.
\end{abstract}

\section{Introduction}

Diabetic nephropathy is a renal disease in which functional changes in the kidneys are believed to play an important pathogenetic part. ${ }^{1}$ Glomerular capillary pressure is increased, as indicated by micropuncture studies in diabetic rats. ${ }^{2}$

\footnotetext{
Departments of Nephrology and Clinical Physiology, Sahlgrenska sjukhuset, Göteborg S-413 45, Sweden

STAFFAN BJÖRCK, MD, registrar

GUDRUN NYBERG, MD, PHD, registrar

GÖRAN GRANERUS, MD, PHD, senior registrar

HANS HERLITZ, MD, PHD, registrar

MATTIAS AURELL, MD, PHD, head of department of nephrology

Department of Medicine, Vänersborg Hospital, Sweden

HENRIK MULEC, MD, registrar

Correspondence to: Dr Björck.
}

The kidney is extremely sensitive to angiotensin II, infusion of which results in increased glomerular capillary pressure. ${ }^{3}$ We therefore studied the acute effect on renal haemodynamics of reducing the angiotensin II concentration by means of an inhibitor of angiotensin converting enzyme, captopril, in patients with diabetic nephropathy. We also evaluated the long term effect of captopril on the progression of renal disease in patients with diabetes.

\section{Patients and methods}

Fifteen patients with insulin dependent diabetes mellitus were studied. All had diabetic nephropathy, the diagnosis being based on the presence of retinopathy, a suitable time relation between the onset of diabetes and proteinuria, and a progressive decline in kidney function. Kidney biopsies in eight patients confirmed the diagnosis. The mean age of the patients was 34 years, and the mean duration of their diabetes was 22 years. All patients had hypertension, and in 14 patients blood pressure was not adequately controlled-that is, diastolic blood pressure was $95 \mathrm{~mm} \mathrm{Hg}$ or higherwhen they were included in the study. The mean (SD) serum creatinine concentration was $186(55) \mu \mathrm{mol} / \mathrm{l}(2 \cdot 1(0 \cdot 6) \mathrm{mg} / 100 \mathrm{ml})$. The mean (SD) haemoglobin $A_{1 c}$ concentration was $10 \cdot 9(1 \cdot 9) \%$.

When treatment with captopril was started the 15 patients were taking the following drugs: frusemide (13), metoprolol or atenolol (12), hydralazine (9), spironolactone (4), nifedipine (1), and prazosin (1).

\section{SHORT TERM EFFECTS OF ANGIOTENSIN CONVERTING ENZYME} INHIBITION

Thirteen patients were given captopril and frusemide in combination, and in one case metoprolol was also used. The glomerular filtration rate and renal plasma flow were measured before and nine days after the start of treatment with captopril, which was given in a dose adjusted to kidney function ( 25 to $100 \mathrm{mg} / \mathrm{day}$ ).

LONG TERM EFFECTS OF ANGIOTENSIN CONVERTING ENZYME INHIBITION

The decline in renal function was studied for a mean of $2 \cdot 8$ (range $1 \cdot 2-7 \cdot 8$ ) years before and $2 \cdot 0$ (range $1 \cdot 0-3 \cdot 5)$ years after the start of treatment with captopril in 14 patients. The other patient was lost to follow up. To assess the 
decline in renal function a mean (SD) of $4.9(1 \cdot 8)$ clearance measurements was performed in each patient before treatment with captopril and $6 \cdot 3(1 \cdot 6)$ after treatment with captopril was started; altogether, 156 measurements were made. In addition to captopril 13 patients received frusemide, one a thiazide, and two metroprolol. When blood pressure was not adequately controlled other drugs were added.

\section{MEASUREMENT OF RENAL FUNCTION}

Glomerular filtration rate was assessed by measuring the clearance of chromium-51 edetic acid. After a single injection plasma clearance and, in patients with more severely impaired renal function, renal clearance were determined. Of 156 measurements made, 119 were of renal clearance. When only plasma clearance values were available they were reduced by $7 \mathrm{ml} / \mathrm{min}$ to correct for the extrarenal clearance in diabetic patients and make measurements with the two methods comparable. ${ }^{4}$ To determine the short term renal haemodynamic effect of captopril renal plasma flow and glomerular filtration rate were measured as the renal clearance of paraaminohippuric acid and ${ }^{51} \mathrm{Cr}$ edetic acid using the constant infusion technique. The mean arterial blood pressure was calculated as the diastolic blood pressure plus one third of the difference between the systolic and diastolic blood pressure. All measurements of renal function are given after correction to $1.73 \mathrm{~m}^{2}$ body surface area.

\section{STATISTICAL METHODS}

Linear regression analysis was used to assess the decline in glomerular filtration rate. The paired $t$ test was used for tests of significance. Mean values are given with standard deviation in parentheses. In addition, a sliding mean value method was used to describe the development of renal function. All 156 clearance measurements were ranked according to time of determination in relation to the start of treatment with captopril. The first mean was calculated on measurements $1-10$, the next on $2-11$, and so on. The successive points were then joined to form a curve, which was extended in time to the last point where 10 or more patients were observed (see fig 2). This calculation was not used for statistical analysis but merely to give a description of how renal function changed with time.

\section{Results}

\section{BLOOD PRESSURE}

After nine days' treatment with captopril blood pressure was unchanged (table I). As more drugs were introduced to improve control of blood pressure and after long term treatment the blood pressure fell. At the end of the study periods $(1 \cdot 0-3.5$ years) the 14 patients were taking a mean of 2.7 drugs compared with 2.8 before treatment with captopril. In addition to captopril treatment comprised: frusemide (13), metroprolol or atenolol (7), labetalol (1), hydralazine (1), felodipine (1), and a thiazide (1). The initial mean (SD) dosage of captopril was $52(22) \mathrm{mg} / 24 \mathrm{~h}$ and the final dosage 51 (19) $\mathrm{mg} / 24 \mathrm{~h}$. The mean (SD) blood pressures were $163(13) / 97(6) \mathrm{mm} \mathrm{Hg}$

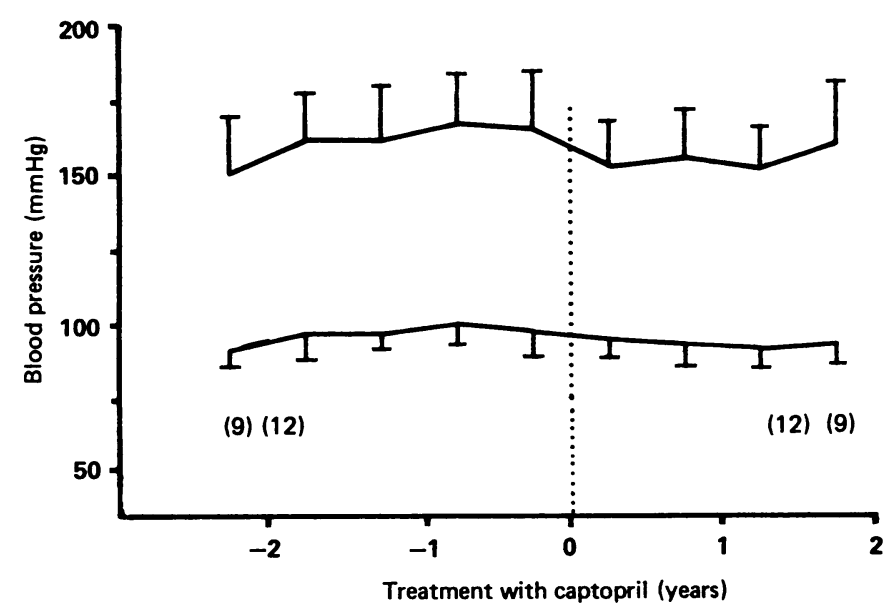

FIG 1-Systolic and diastolic blood pressure in 14 patients with diabetic nephropathy before and after treatment with captopril. Values are given as mean (SD). The number of patients is indicated in parentheses when less than 14 .
TABLE I-Short term effects of captopril in 13 patients with diabetic nephropathy. Values are mean $(S D)$

\begin{tabular}{lcc}
\hline & $\begin{array}{c}\text { Before } \\
\text { treatment }\end{array}$ & $\begin{array}{c}\text { After } 9 \text { days' } \\
\text { treatment }\end{array}$ \\
\hline $\begin{array}{l}\text { Clearance of }{ }^{51} \mathrm{Cr} \text { edetic acid }\left(\mathrm{ml} / \mathrm{min} / 1 \cdot 73 \mathrm{~m}^{2}\right) \\
\begin{array}{l}\text { Clearance of para-aminohippuric acid } \\
\left(\mathrm{ml} / \mathrm{min} / 1 \cdot 73 \mathrm{~m}^{2}\right)\end{array}\end{array}$ & $37(11)$ & $38(13)$ \\
$\begin{array}{l}\text { Filtration fraction }(\%) \\
\text { Blood pressure }(\mathrm{mm} \mathrm{Hg})(\mathrm{n}=10)\end{array}$ & $265(65)$ & $302(80)^{\star}$ \\
$\quad \begin{array}{c}\text { Systolic } \\
\text { Diastolic }\end{array}$ & $14 \cdot 3(2 \cdot 5)$ & $12 \cdot 8(2 \cdot 9) \dagger$ \\
\end{tabular}

${ }^{\star} \mathrm{p}<0.05,+\mathrm{p}<0.025$.

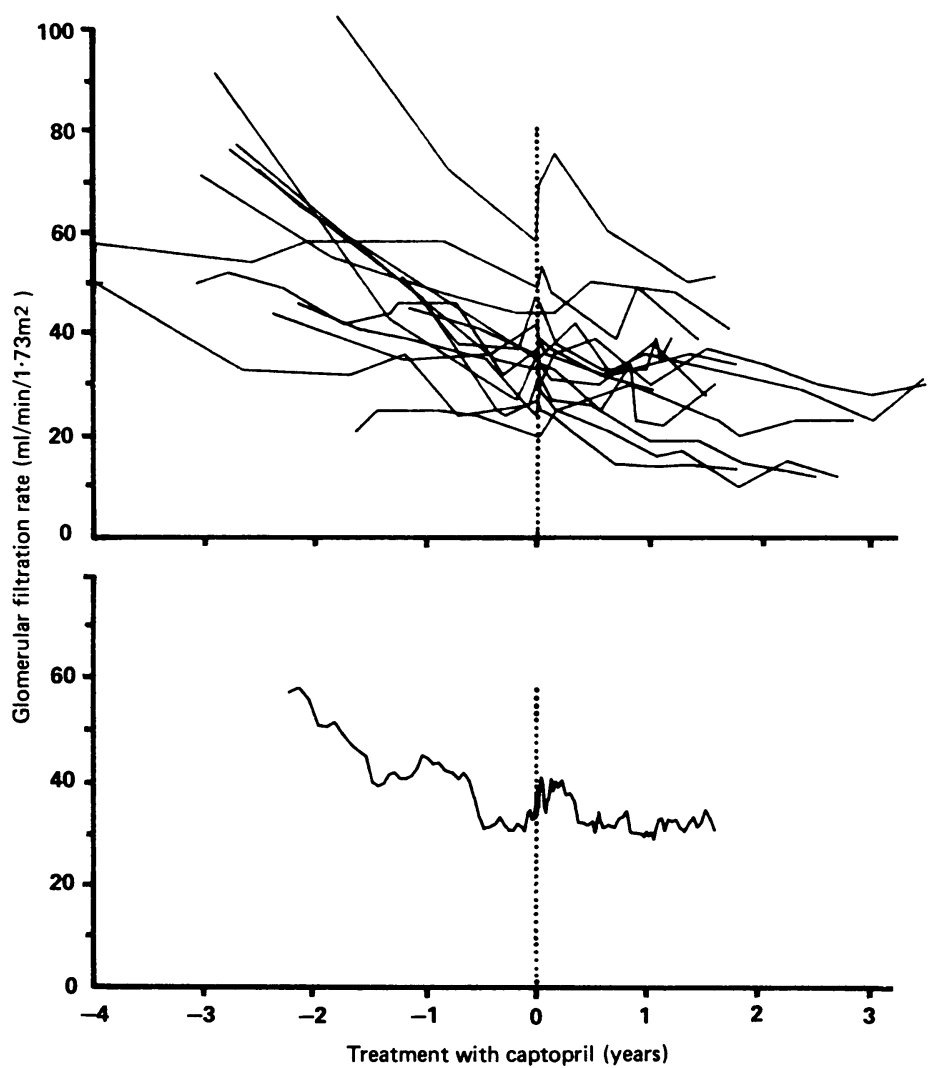

FIG 2-Top: deterioration in glomerular filtration rate in 14 patients with diabetic nephropathy before and after treatment with captopril. Bottom: sliding mean value of glomerular filtration rate was drawn when there were 10 or more patients (for explanation see text).

before and $155(14) / 94(6) \mathrm{mm} \mathrm{Hg}$ during treatment with captopril $(\mathrm{p}<0.005$ systolic, and $p<0.02$ diastolic) (table II). Mean arterial pressure was reduced by only $5 \mathrm{~mm} \mathrm{Hg}$, from 119 (6) to $114(7) \mathrm{mm} \mathrm{Hg}(\mathrm{p}<0.005)$. Figure 1 shows the change in blood pressure.

\section{RENAL FUNCTION}

Table I shows the short term effects of captopril on renal function. Renal plasma flow increased, glomerular filtration rate remained unchanged, and filtration fraction decreased in the presence of an unchanged blood pressure.

Figure 2 and table II show the long term effects of captopril on renal function. The mean (SD) deterioration in glomerular filtration rate was $10 \cdot 3$ $(7.8) \mathrm{ml} / \mathrm{min} /$ year before and $5.5(3.9) \mathrm{ml} / \mathrm{min} /$ year $(\mathrm{p}<0.02)$ after treatment with captopril. During the latter period of treatment with captopril glomerular filtration rate showed only slight deterioration (fig 2 ). After six months' treatment with captopril the mean (SD) decline in renal function in the 14 patients was $2.4(4.6) \mathrm{ml} / \mathrm{min} /$ year $(p<0.005 v$ before captopril). There was no correlation between the individual reduction in mean arterial pressure and the reduction in rate of decline of renal function $(r=-0 \cdot 15)$. In two patients blood pressure did not fall. Their glomerular filtration rates decreased from 20.4 and $9.5 \mathrm{ml} / \mathrm{min}$ before to 9.7 and $2.3 \mathrm{ml} / \mathrm{min}$, respectively, after treatment with captopril. There was no significant 
correlation between the rate of decline in glomerular filtration rate and mean arterial pressure before or during treatment with captopril $(r=0.13$ and 0.10 respectively).

\section{SERUM CREATININE AND PROTEIN EXCRETION}

The mean (SD) serum creatinine concentration was $186(55) \mu \mathrm{mol} / \mathrm{l}(2 \cdot 1$ $\mathrm{mg} / 100 \mathrm{ml})$ before treatment with captopril and $222(84) \mu \mathrm{mol} / \mathrm{l}(2.5 \mathrm{mg} / 100$ $\mathrm{ml}$ ) at the end of the follow up period.

The mean (SD) urinary protein excretion (table II) was $2.9(2.0) \mathrm{g} / 24 \mathrm{~h}$ before and $2 \cdot 8(1 \cdot 9) \mathrm{g} / 24 \mathrm{~h}$ after treatment with captopril. When measured immediately before and at the end of the observation period on captopril the protein excretion was reduced in 10 of the 14 patients, but not significantly. Protein excretion was not significantly correlated with the rate of deterioration in glomerular filtration rate or mean arterial pressure. pressure, inhibition of angiotensin converting enzyme with enalapril reduced glomerular hypertension and limited the development of proteinuria and glomerular lesions. ${ }^{9}$ In a comparative study treatment with enalapril reduced mesangial expansion after renal ablation more than a more efficient antihypertensive treatment with reserpine, hydrochlorothiazide, and hydralazine. ${ }^{10}$ It has recently been shown in diabetic rats that inhibition of angiotensin converting enzyme with enalapril leads to reduced glomerular filtration pressure and correction of albuminuria. ${ }^{11}$ In patients with diabetic nephropathy severe proteinuria has been reduced by treatment with captopril even though the blood pressure was not significantly reduced. ${ }^{12}$ For these reasons it seems possible that inhibitors of angiotensin converting enzyme have favourable renal haemodynamic effects in diabetic nephropathy.

In our patients blood pressure was unchanged after nine days'

TABLE II-Blood pressure, change in glomerular filtration rate, and urinary protein excretion before and after treatment with captopril

\begin{tabular}{|c|c|c|c|c|c|c|c|c|}
\hline \multirow[b]{2}{*}{ Case No } & \multicolumn{2}{|c|}{$\begin{array}{l}\text { Investigation } \\
\text { period (years) }\end{array}$} & \multicolumn{2}{|c|}{$\begin{array}{l}\text { Blood pressure } \\
(\mathrm{mm} \mathrm{Hg})\end{array}$} & \multicolumn{2}{|c|}{$\begin{array}{c}\text { Decrease in } \\
\text { glomerular filtration } \\
\text { rate } \\
(\mathrm{ml} / \mathrm{min} / \text { year })\end{array}$} & \multicolumn{2}{|c|}{$\begin{array}{l}\text { Urinary protein } \\
\text { excretion } \\
(\mathrm{g} / 24 \mathrm{~h})\end{array}$} \\
\hline & Before & After & Before & After & Before & After & Before & After \\
\hline 1 & $2 \cdot 15$ & $2 \cdot 50$ & $170 / 98$ & $170 / 91$ & $9 \cdot 7$ & $7 \cdot 2$ & 3.0 & $2 \cdot 9$ \\
\hline 2 & $2 \cdot 70$ & 1.60 & $158 / 108$ & $154 / 99$ & $16 \cdot 9$ & $4 \cdot 1$ & $6 \cdot 4$ & $5 \cdot 8$ \\
\hline 3 & $2 \cdot 76$ & 1.79 & $149 / 97$ & $142 / 97$ & $19 \cdot 7$ & $9 \cdot 0$ & $5 \cdot 2$ & $5 \cdot 8$ \\
\hline 4 & $1 \cdot 15$ & 3.49 & $187 / 102$ & $172 / 99$ & $7 \cdot 5$ & 1.6 & $1 \cdot 3$ & 1.0 \\
\hline 5 & 4.58 & $2 \cdot 84$ & $162 / 98$ & $144 / 95$ & $6 \cdot 0$ & $2 \cdot 2$ & $2 \cdot 3$ & 1.0 \\
\hline 6 & $1 \cdot 21$ & $1 \cdot 21$ & $165 / 94$ & $151 / 90$ & $5 \cdot 3$ & 6.8 & $3 \cdot 4$ & 1.5 \\
\hline 7 & 1.63 & $2 \cdot 70$ & $155 / 103$ & $136 / 90$ & $1 \cdot 1$ & $4 \cdot 3$ & $1 \cdot 3$ & $1 \cdot 1$ \\
\hline 8 & 3.06 & 1.52 & $184 / 94$ & $170 / 96$ & $5 \cdot 0$ & $1 \cdot 1$ & $1 \cdot 1$ & 1.6 \\
\hline 9 & 1.79 & $1 \cdot 60$ & $161 / 105$ & $159 / 104$ & $25 \cdot 0$ & $15 \cdot 0$ & $1 \cdot 3$ & $2 \cdot 2$ \\
\hline 10 & $7 \cdot 78$ & 1.45 & $144 / 91$ & $141 / 88$ & 1.8 & $7 \cdot 9$ & $1 \cdot 3$ & $1 \cdot 0$ \\
\hline 11 & $2 \cdot 89$ & 1.04 & $157 / 97$ & $158 / 99$ & $20 \cdot 4$ & $9 \cdot 7$ & $2 \cdot 5$ & $3 \cdot 7$ \\
\hline 12 & $2 \cdot 37$ & $3 \cdot 47$ & $158 / 90$ & $155 / 86$ & 1.5 & $2 \cdot 9$ & 0.8 & $2 \cdot 9$ \\
\hline 13 & $2 \cdot 50$ & 1.79 & $147 / 92$ & $139 / 82$ & $14 \cdot 6$ & $3 \cdot 3$ & $5 \cdot 5$ & $2 \cdot 5$ \\
\hline 14 & 3.02 & 1.73 & $180 / 92$ & $180 / 94$ & $9 \cdot 5$ & $2 \cdot 3$ & $5 \cdot 8$ & $6 \cdot 1$ \\
\hline Mean & $2 \cdot 83$ & 2.05 & $163 / 97$ & $155 \ddagger / 94 \dagger$ & $10 \cdot 3$ & $5.5 t$ & $2 \cdot 9$ & $2 \cdot 8$ \\
\hline SD & 1.67 & $0 \cdot 80$ & $13 / 6$ & $14 / 6$ & $7 \cdot 8$ & 3.9 & $2 \cdot 0$ & 1.9 \\
\hline
\end{tabular}

${ }^{\star}$ Mean of determinations before and after treatment with captopril. $\mathrm{tp}<0.02$ and $\neq \mathrm{p}<0.005 v$ before treatment with captopril.

\section{Discussion}

Our results show a striking reduction in the rate of deterioration of glomerular filtration rate after treatment with captopril. Before treatment renal function showed a steady deterioration, whereas after six months of captopril treatment the glomerular filtration rate remained almost constant, with a loss of only $2 \cdot 4 \mathrm{ml} / \mathrm{min} / \mathrm{year}$. This figure is the lowest reported for a group of patients with such advanced diabetic nephropathy.

In the early stages of insulin dependent diabetes mellitus both glomerular filtration rate and renal plasma flow increase. Glomerular filtration rate usually increases more than renal plasma flow, which results in an increased filtration fraction. The increase in glomerular filtration rate is believed to be due to greater renal plasma flow and also raised glomerular filtration pressure. ${ }^{12}$

Interruption of the renin-angiotensin system leads to increased renal plasma flow, but glomerular filtration rate is less affected. This results in a decreased filtration fraction, probably reflecting a reduced glomerular filtration pressure. In the euvolaemic normal state these effects are negligible but they are exaggerated in the presence of raised renin concentrations. ${ }^{5}$ This rationale focused our interest on angiotensin converting enzyme inhibitors.

Christlieb et al suggested that in patients with insulin dependent diabetes mellitus with nephropathy the renin-angiotensin system was suppressed due to impaired synthesis of active renin. ${ }^{6}$ We have shown, however, that even patients with advanced diabetic nephropathy have an active renin-angiotensin system provided that overhydration is appropriately treated. ${ }^{7}$ Similar findings have been described in diabetic patients without renal disease. ${ }^{8}$

In experimental renal failure in rats induced by ablation of $85 \%$ of the renal mass, which also results in increased glomerular filtration treatment with captopril. After long term treatment, however, mean arterial blood pressure was significantly reduced but only by $5 \mathrm{~mm} \mathrm{Hg}$, and the reduction was achieved only after adding more drugs. With captopril included in these combinations, however, the same number of drugs resulted in significantly lower blood pressure. Thus captopril is of value in controlling hypertension in patients with diabetic nephropathy. No side effects were recorded in our patients.

After short term treatment with captopril renal plasma flow was increased and the filtration fraction decreased. The glomerular filtration rate was unaffected. Inhibition of angiotensin converting enzyme in diabetic nephropathy thus leads to renal vasodilatation and a further decrease in filtration fraction, which is best explained by reduced filtration pressure. Our findings indicate that the reninangiotensin system is important for the regulation of renal function and maintenance of glomerular filtration pressure in patients with diabetic nephropathy and hypertension. The role of the reninangiotensin system in the hyperfiltration seen in the early stages of insulin dependent diabetes mellitus is not known, but raised renin concentrations have recently been found in these patients. ${ }^{13}$

Treatment which reduces blood pressure has been shown to retard the progression of the renal disease. ${ }^{14}$ is In 11 patients with diabetic nephropathy and accelerating hypertension a reduction in the mean arterial pressure by $14 \mathrm{~mm} \mathrm{Hg}$ was followed by a reduction of the rate of deterioration of renal function from 10.9 to 4.7 $\mathrm{ml} / \mathrm{min} /$ year in 10 patients. ${ }^{14}$ In the other patient hypertension did not improve and the deterioration continued at the same rate. ${ }^{14} \mathrm{We}$ achieved a more striking effect after a reduction in mean arterial pressure of only $5.0 \mathrm{~mm} \mathrm{Hg}$.

We consider it unlikely that the beneficial effect in our patients can be explained by the reduction in blood pressure alone. Indeed, 
there was no correlation between the effect on blood pressure and the reduction in the rate of deterioration of renal function. In two of our patients the rate of deterioration of renal function was substantially reduced, although the blood pressure was not improved.

The effect of captopril on mean urinary protein excretion was not significant, but proteinuria was reduced in most patients. Recently, Taguma et al reported that treatment with captopril reduced proteinuria in diabetic nephropathy. ${ }^{12}$ The patients in their study, however, differed from ours. They were much older and had more severe proteinuria; congestive heart failure was common among their patients but was present in none of our patients. Differences between the patients may therefore explain the different effects of captopril on proteinuria.

Captopril is an efficient and safe antihypertensive drug for patients with diabetic nephropathy. Our findings support the hypothesis that inhibition of angiotensin converting enzyme protects the kidney by its effects on renal haemodynamics.

\section{References}

1 Mogensen CE. Glomerular filtration rate and renal plasma flow in short term and long term juvenile diabetes mellitus. Scand f Clin Lab Invest 1971;28:91-100.
2 Hostetter TH, Rennke HG, Brenner BM. The case for intrarenal hypertension in the initiation and progression of diabetic and other glomerulopathies. Am f Med 1982;72:375-80.

3 Blantz RC, Konnen KS, Tucker BJ. Angiotensin II effects upon the glomerular microcirculation and ultrafiltration coefficient of the rat. $f$ Clin Invest 1976;57:419-34

4 Nordén G, Björck S, Granerus G, Nyberg G. Renal function measurement in diabetic nephropathy-evaluation of five methods. Transplant Proc (in press).

5 Hall JE, Guyton AC, Jackson TE, Coleman TG, Lohmeier TE, Trippodo NC. Control o glomerular filtration rate by renin-angiotensin system. Am J Physiol 1977;233:F366-72.

6 Christlieb AR, Kaldany A, D'Elia JA. Plasma renin activity and hypertension in diabetes mellitus. Diabetes 1976;25:969-74.

Björck S, Delin K, Herlitz $\mathrm{H}$, Larsson $\mathrm{O}$, Aurell $\mathrm{M}$. Renin secretion in advanced diabetic nephropathy. Scand f Urol Nephrol 1984;79 (suppl):53-7.

8 Weidman P, Beretta-Piccoli C, Keusch G. Sodium-volume factor, cardiovascular reactivity and hypotensive mechanism of diuretic therapy in mild hypertension associated with diabetes mellitus. Am J Med 1979;67:779-84.

9 Anderson S, Meyer TW, Rennke HG, Brenner BM. Control of glomerular hypertension limits glomerular injury in rats with reduced renal mass. $\mathcal{F}$ Clin Invest 1985;76:612-9.

10 Raii L, Chiou X, Owens R, Wrigley B. Therapeutic implications of hypertension-induced glomerular injury. Am $\mathcal{F}$ Med 1985;79(suppl 3C):37-41.

11 Zatz R, Meyer TW, Dunn BR, Anderson S, Troy JL, Brenner BM. Lowering of arterial pressure limits glomerular hypertension and albuminuria in experimental diabetes. Kidney Int 1985;27 252.

12 Taguma Y, Kitamoto Y, Futaki G, et al. Effect of captopril on heavy proteinuria in azotemic diabetics. N Engl f Med 1985;313:1617-20.

13 Wiseman MJ, Drury PL, Keen H, Viberti GC. Plasma renin activity in insulin dependent diabetes with raised glomerular filtration rate. Clin Endocrinol 1984;21:409-14.

14 Parving HH, Andersen AR, Smidt UM, Svendsen PA. Early aggressive antihypertensive treatment reduces rate of decline in kidney function in diabetic nephropathy. Lancet 1983;i:1175-8.

15 Mogensen CE. Long-term antihypertensive treatment inhibiting progression of diabetic nephropathy. BrMed J 1982;285:685-8.

(Accepted 2I May 1986)

\title{
Identifying men at high risk of heart attacks: strategy for use in general practice
}

\author{
A G SHAPER，S J POCOCK， A N PHILLIPS， MARY WALKER
}

\begin{abstract}
A strategy was devised for identifying men at high risk of acute myocardial infarction or sudden ischaemic death. A risk score was devised using cigarette smoking, mean blood pressure, recall of ischaemic heart disease or diabetes mellitus diagnosed by a doctor, history of parental death from "heart trouble," and the presence of angina reported on a questionnaire. The top fifth of the score distribution identified $53 \%$ of ischaemic heart disease cases-that is, men who subsequently experienced major ischaemic heart disease over the next five years. The addition of serum total cholesterol concentration and electrocardiographic evidence only slightly improved prediction (to $59 \%$ ) and would have considerably increased the cost and effort of screening.

Using this risk score on an opportunistic basis could be particularly valuable in general practice. Management of this high risk group is regarded as appropriate medical care and is complementary to the population approach to preventing ischaemic heart disease. Such a strategy for reducing the incidence of and mortality from ischaemic heart disease in men at high risk would also increase professional and public awareness of the need for preventive action.
\end{abstract}

\footnotetext{
Department of Clinical Epidemiology and General Practice, Royal Free Hospital School of Medicine, London NW3 2PF

A G SHAPER, FRCP, FFCM, professor of clinical epidemiology

$S$ J POCOCK, MSC, PHD, reader in medical statistics

A N PHILLIPS, MSC, PHD, statistician

MARY WALKER, SRN, SCM, research administrator

Correspondence and requests for reprints to: Professor Shaper.
}

\section{Introduction}

The United Kingdom has one of the highest death rates for ischaemic heart disease, especially in Scotland and Northern Ireland. ${ }^{1}$ This high mortality is matched by a high prevalence of ischaemic heart disease, ${ }^{2}$ and the established risk factors (raised serum total cholesterol concentration, cigarette smoking, and raised blood pressure) are common in Great Britain. ${ }^{3}$ To diminish substantially the impact of ischaemic heart disease in Britain almost certainly requires substantial and prolonged changes in the population's diet, cigarette smoking habits, blood pressure, and physical activity. Although such a population approach may be most effective in the long run, there is a current need to identify those people with a particularly high risk of suffering major events due to ischaemic heart disease. This paper aims to provide a means of identifying those men at highest risk of a heart attack in the belief that such people require appropriate medical care, both to improve their quality of life and to reduce the risk of heart attacks. This high risk approach is regarded as strictly complementary to the population approach, since it is difficult to accept one of these strategies to the exclusion of the other.

\section{Subjects and methods}

The data used were derived from the British Regional Heart Study, which examined 7735 men aged 40-59 randomly selected from the age-sex registers of representative group general practices in 24 towns in England, Wales, and Scotland. The criteria for selecting the towns, the general practices, and the subjects, as well as the methods of data collection, have been presented. ${ }^{2-6}$ The 24 towns were selected from those with populations of 50 000-100 000; they represented the full range of cardiovascular disease mortality and included towns in all the major standard regions. The general practice selected in each town had a social class distribution representative of the town. The men were selected at random from age-sex registers; no attempt was made to exclude subjects with cardiovascular disease, and there was a $78 \%$ response rate. 